14. Elizabeth Lindsay Davis, Lifting as They Climb (Washington, DC: National Association of Coloured Women, 1933), http://cbw.iath.virginia.edu/books_display.php?id=1555.

\title{
Fin de Siècle
}

\section{MATTHEW POTOLSKY}

$\mathrm{F}$ IN de Siècle is a messy term, applicable to such a wide range of phenomena as to be nearly incoherent. And yet, it serves an important if underappreciated function in Victorian Studies, disrupting the hermetically sealed bell jar that any period identified with the life of a monarch can become. Defined by a sense of crisis and opposition, fin de siècle names those things that were never quite assimilated into the high-Victorian moment; openly cosmopolitan, it places that moment in a global context it often resisted.

Fin de siècle was first used in Britain in 1890, having been borrowed, accent and all, from France, where it had an earlier popular debut as the title of an 1888 play. Most obviously, it is a period term, but like so many other such terms, it also stands in for a characteristic style, set of affects, and dominant literary or artistic forms. A. O. Lovejoy famously argued that the word "romanticism" really designates at least three distinct "thought-complexes," each an "exceedingly unstable intellectual compound." "Fin de siècle, I would argue, in Lovejoy's spirit, designates no less than four "compounds": a program, a mood, and an intellectual milieu, as well as a period in cultural history. These compounds are all "unstable": changing the composition of one changes the nature of the others.

Consider the many different period definitions in fin-de-siècle studies. In an influential essay from 1974, "Truth in Labelling: Pre-Raphaelitism, Aestheticism, Decadence, Fin de Siècle," Ruth Z. Temple argues that the period designated by fin de siècle should properly be restricted "to the last decade of the century." 2 This restriction accords with many early scholarly studies, notably Holbrook Jackson's The Eighteen Nineties (1919). ${ }^{3}$ But contrary to W. B. Yeats's sardonic claim that "in 1900 everybody got down off his stilts," the term fin de siècle tends in practice to cover a longer 
span. ${ }^{4}$ The journal English Literature in Transition, which has done much to promote scholarly work in the field, takes in the period from 1880-1920; Sally Ledger and Scott McCracken's collection Cultural Politics at the Fin de Siècle (1995) picks the dates 1880-1914; the chronology in the Cambridge Companion to the Fin de Siècle (2007) runs from 1885 to the death of Queen Victoria in 1901; and the recent collection The Fin-de-Siècle World (2014) claims the period 1870-1914. ${ }^{5}$ Many treatments of the fin de siècle end it with the immediate aftermath of Oscar Wilde's 1895 trials, acknowledging the centrality of Wilde to the moment. Seen as a global phenomenon, the period extends later into the twentieth century, reflecting the uneven spread of Occidental trends to America, Eastern Europe, Asia, and Latin America.

There is a logic, however obscure, to each period designation. The longest designation, roughly corresponding to a familiar period in French literary history, understands fin de siècle as the name for a particular artistic and cultural program leading to modernism in the twentieth century. In this use, the term gathers under a single umbrella the various avant-garde movements in late-Victorian culture-decadence, aestheticism, arts and crafts, and so forth-defined by their cosmopolitanism and their challenge to reigning conventions in art and society. The challenge arguably begins in 1848 with the first meeting of the Pre-Raphaelite Brotherhood, whose theoretically driven artworks set the tone for all of the movements that followed, though this tone only congealed into a recognizable stance in the 1870s, with the publication of Dante Gabriel Rossetti's Poems (1870) and Walter Pater's Studies in the History of the Renaissance (1873). Given a body blow by Wilde's trials, the program was eventually supplanted by Modernism, the story goes, in the years after World War I.

The confines of the period change again when we consider fin de siècle as the name for a mood or for an intellectual milieu. In both cases, its time frame shrinks while the conceptual boundaries expand. As a mood, fin de siècle designates the palpable sense of anxiety and pessimism that succeeded the optimism of the high-Victorian momentwhat Max Nordau ominously calls the "Dusk of Nations." ${ }^{6}$ This mood, widely diagnosed during the last years of the century, brings together a variety of contemporary feelings, from an intuition of imperial decline, to discomfort at the increasingly evident contradictions of global capitalism, and the fears roused by the looming end of a century: a sense of closure and decay founded on the anthropomorphic analogy between an era and a life. In this usage, the term is typically restricted to the 
1890s, and perhaps a few years before or after. Seen, by contrast, as a cultural and intellectual milieu, the term links the various literary trends of the age-the neo-Gothic of Dracula, the colonial narratives of She or Heart of Darkness, the pessimistic naturalism of Thomas Hardy's Jude the Obscure, the New Woman experimentalism of George Edgerton's Keynotes — with a swirl of coeval intellectual movements: socialism, feminism, anarchism, sexology, degeneration theory, Uranianism, cosmopolitanism. This usage, which came to the fore in the 1990s, derives from Raymond Williams's designation of the years 1880-1914, in Culture and Society, as an "interregnum," marked by the decay of Victorian hegemony and the early stirrings of what would become post-War culture. ${ }^{7}$ Rather than describing a mood or an exclusive avant-garde program, the term here captures a moment of transition, a unique confluence of international styles, movements, and theories in a particularly charged historical context.

Lovejoy was convinced that no one could do serious academic work on Romanticism without nailing down what they were talking about, and it might be argued that all four "compounds," particularly the last two, are the product of a certain confirmation bias. But period and stylistic terms are also heuristics, generative of new definitions, not simply the final results of conclusive analyses. Seen in this light, the messiness of the term fin de siècle is a boon rather than a bane.

\section{NOTES}

1. A. O. Lovejoy, "On the Discrimination of Romanticisms," PMLA 39, no. 2 (1924): 229-53, 236.

2. Ruth Z. Temple, "Truth in Labelling: Pre-Raphaelitism, Aestheticism, Decadence, Fin de Siècle," English Literature in Transition 17, no. 4 (1974): 201-22, 201.

3. Holbrook Jackson, The Eighteen Nineties (London: Grant Richard, 1922).

4. W. B. Yeats, "Introduction," in The Oxford Book of Modern Verse, 1892 1935 (New York: Oxford University Press, 1937), xi.

5. Sally Ledger and Scott McCracken, eds., Cultural Politics at the Fin de Siecle (Oxford: Oxford University Press, 1995); Gail Marshall, ed., The Cambridge Companion to the Fin de Siècle (Cambridge: Cambridge University Press, 2007); Michael Saler, ed., The Fin-de-Siècle World (London: Routledge, 2014). 
6. Max Nordau, Degeneration (Lincoln: University of Nebraska Press, 1993), 1.

7. Raymond Williams, Culture and Society, 1780-1950 (New York: Columbia University Press, 1983).

\title{
Form
}

STEPHEN ARATA

\begin{abstract}
A TRUISM: to understand a work of literature you must attend not just to what it says but to how it is made. That is, you must attend to form. A second truism: it can be difficult to persuade students of the truth of that truism. I am not suggesting that students never respond to a work's formal features, only that such responses tend to be felt in the blood and felt along the heart rather than brought fully into consciousness for the purposes of reflection or analysis. And, they sometimes tell me, that's as it should be. Implicit in their resistance to formal analysis is the suspicion that it is at best tangential to and at worst destructive of what is most valuable in any particular work of literature. This is the case whether the work in question is a lyric poem or a three-decker novel. Why master scansion if the point of reading poetry is to be made to feel physically as if the top of your head were taken off? Why scrutinize modes of narration or map out textual networks when your research interests center on questions of class or gender or empire that are treated thematically, and with great power, in the novels you're studying? Formal analysis can seem pedantic or hermetic (or both), a set of technical exercises designed to numb aesthetic response or else to quarantine literature from the richness and complexity of lived experience.

Outside the classroom, formalist criticism flourishes. A renewed attention to form has led to some extraordinary work over the past two decades. Thanks to this work, the questions we ask about form are richer, more various, and more supple than they once were. Those questions can invigorate not just our scholarship but our pedagogy, not least by making formal analysis seem less pedantic or hermetic (or both). Yet their very richness and variety only deepen the pedagogic challenges. Literary form is a protean concept, and students may now wonder where one
\end{abstract}

